\title{
The Effect of Diversity in Board of Directors to Financial Performance: Evidence in Indonesia
}

\author{
Yasmin Ridwan Putri ${ }^{1 *}$, Dwi Nastiti Danarsari² \\ 1,2Universitas Indonesia, Faculty of Economics and Business, Management Science Department, Depok, \\ West Java, 16424, Indonesia.
}

* Corresponding Author: Yasmin Ridwan Putri, Faculty of Economics and Business, Management Science Department, Depok, Universitas Indonesia, West Java, Indonesia, putriyasminr@gmail.com

\begin{abstract}
This paper aims to examine whether diversity in gender, nationality, and age in the board of directors of banks in Indonesia could affect the financial performance of those banks. We used conventional banks' data in Indonesia in the year of 2014 to 2018 as a sample of this research. Based on the empirical result using fixed effect approach and the Generalized Methods of Moment (GMM) analysis, we find that diversity in gender in the board of directors does not affect the performance of banks in Indonesia. This could be the result of the little amount of female representative in the board of directors. In contrast diversity in age and diversity in nationality in the board of directors has an effect to the financial performance of banks in Indonesia. We used two measurement to represent financial performance in this study, which are measured by Tobin's $Q$ that represent measurement based on market and Return on Asset (ROA) that represent measurement based on accounting.
\end{abstract}

Keywords: Age, Board of Directors, Diversity, Financial Performance, Gender, Nationality

\section{INTRODUCTION}

The fall of several big firms such as Enron, Xerox, and Parmalat have been a big slap to the economic world. Those firms fall because of a weak corporate governance. Very little monitoring, miscommunication between top management and lower management could be one of the cases of weak corporate governance. From those cases we could see how much corporate governance could affect a firm. Firms has been working actively trying to implement good corporate governance (GCG) to the firms. It has to do with a requirement from investors or analysts. Firms with good corporate governance seen as a capable firm that can generate revenue for the shareholders. Good corporate governance was used to avoid agency problem. Firms with agency problem has a risk of decreased share price as it was captured by financial market (McColgan, 2001). Several ways to decrease the chance of agency problem are with implement a good corporate governance and giving incentives (Jensen \& Meckling, 1976). There are several aspects of good corporate governance. One of the aspects of good corporate governance is independency. It means that firm has to be manage independently to avoid bias or intervention from internal or external. To achieve independency, firm can do several ways. One of the ways to increase independency to the firm is increasing the diversity within firm. Diversity in the firm could be 
implemented in the lower management and top management. There are two types of diversity according to (Kang et al., 2007). First, observable diversity which is differences that can be seen with our own eyes such as gender, ethnicity, and age. Second, less visible diversity which is differences that cannot be seen directly such as experience and educational background. Diversity on race, religion, nationality, educational background, gender and ethnicity are the main striking differences that firms faces (Manning, 2019).

Diversity in board of directors believed has a big role to the effectiveness of corporate governance of the firm (Pathan \& Faff, 2013). Board of directors have a big role to mitigate the conflict that might arose between shareholder and management (Fama et al., 2007). Board diversity has several advantages to the firm. In resource dependent theory, diversity also can lead to a better financial flexibility from the increase of potential investor, cross-border technology and broader knowledge (Fogel et al., 2013). In resource dependent theory, suggests that board members will have a potential to provide various resources that would be valuable and beneficial to the firm that could result an increase in the performance. In an article from Forbes (Myatt, 2013), other several advantages that the firms could achieve a better and faster decision making and also problem solving. It achieved because of the many perspective that firms can get from diverse board members. In 2003, Norway made an official law that firms' board members must have at least one female member. In September 2018, United States has made the same move to require firms to have one female as a board member, and that number would increase in the next several years. In Southeast Asia, some ASEAN countries have established ASEAN Corporate Governance Scorecard (ACGS). ACGS was established with a goal that public listed firms in Indonesia, Malaysia, Philippine, Singapore, Thailand and Vietnam could increase their corporate governance. One of the aspects of it is diversity in board of directors and management. In 2017 Indonesia Central Bureau of Statistic reports that there is an increase of 2.34 percent of woman in the workforce (Jawapos, 2017). In 2012, the percentage of woman in overall board (board of commissioner and board of directors) in Indonesia in $\mathbf{1 1 . 6}$ percent which was lower than Europe, North America and Australia, however that number is still slightly bigger than other countries in Asia such as Hongkong, Malaysia, Singapore and Japan (Dieleman, 2012). In an article from Catalyst in 2018, the number of women board members globally are 14.8 percent (Catalyst, 2018).

(Pathan \& Faff, 2013)argues that woman members gave a positive effect to bank performance in pre-Sarbanes-Oxley period, but that effect decreased in Sarbanes-Oxley period and crisis period. In the study by (García-meca et al., 2015) also argue that women board member and foreign board member has a little effect to banks' performance in 7 countries. There is a possibility of benefit in bank performance with expansion of board gender diversity in a well-managed bank (Owen \& Temesvary, 2018). On todays' business, a lot of firms have made an effort of going international. With that the demand for board members to understand foreign market or has a network to help firm to enter the foreign market (Carpenter et al., 2001). (Estélyi \& Nisar, 2016) argues board with members with various nationalities will give a positive effect to day-to-day performance of the firm. Foreign members also could give a new creativity and innovation that would benefit the firm. On the other hand, board members' age plays an important role of how they solve problem or make decision for the firm. Board of directors with members from various ages and generations could give a various insight, perspective and individual values that will affect the quality of problem solving and decisions making process that would benefit the firm (Kang et al., 2007; Talavera et al., 2018).

Previous studies have been focused in developed countries and several industries. There are several studies on diversity in emerging markets' firms but the numbers is very little compared to studies in developed countries. The reason banking sector selected as the sample is because of the different role the banks' board members has compare to other board of directors in the different industries. Banks' board members have a big responsible to prevent failure which could cost a spillover effect to other banks. This research use banks in Indonesia as the sample data with research period from 2014 to 2018. Syariah bank is not included to the sample to generalize the financial data of the sample. The sample also need to have a full data for the research period. 
The rest of the paper is organized as follows. Section 2 reviews the main theoretical ideas, previous studies and hypotheses development. In section 3 we describe briefly data, variable and methodology used. Section 4 we presented result and findings of this research. Section 5 offers the conclusion of this research.

\section{LITERATURE REVIEW}

\section{TWO-TIER BOARD}

There are two types of board systems that are known which are one-tier board and two-tier board. Firms with one-tier board has only one board in the organizational structure to do the monitoring and also run everyday management of the firms (Boglárka, 2012). USA, UK, Malaysia and Singapore are the example of several countries that applied one-tier board system. The number of board members are usually smaller in one-tier board system firm and also the boards are divided into three parts. In most cases the role of chairman of the board is held by the chief executive officer. Meanwhile in firms with two-tier board has two boards in their organizational structures. One board is responsible for the monitoring function and the other responsible for the day-to-day management. Several countries that adopted two-tier boards are Germany and Japan. There are some advantages and disadvantages between the two board systems. There is a possibility of a dominant boards' chairman and a possible "relationship" between independent of non-independent members in a one-tier board firm although with one-tier board system the flow of information is faster and easier to understand. Meanwhile in a firm with twotier board system could achieve an efficient and better monitoring through separation of function between boards (Block et al., 2016).

According to corporation law, firms in Indonesia adopts the two-tier board system. Firms in Indonesia have two boards, namely Dewan Komisaris or Board of Commissioners who responsible as the monitoring function and Dewan Direksi or Board of Directors who responsible for the everyday management of the firm.

\section{BOARD DIVERSITY}

Based on both agency and resource dependent theory, board of directors' diversity would help firm to avoid agency problem by eliminating dominant group that can lead to bias decision and also produce various information. Banks' board members have a slightly different responsibility compared to board member in other industries. Beside their responsibility to the shareholder and other stakeholder, banks' board of directors have a responsible to the securities, exchange regulators and banking regulators. Because failure in one bank could affect other banks which called a spillover effect (García-meca et al., 2015). Bank also usually has more board members than other firm in different industries.

In their research, (Adams \& Ferreira, 2009) argues that board that has diversity in gender would have a better monitoring and better performance. Those findings were supported by (Ghosh, 2016) that argues that woman in the boardroom would increase the stability of the bank in India. On another study, gender diversity believed could lead to an increase in firms' portfolio risk (Berger et al., 2014).

Meanwhile (Yang et al., 2019) argues that of Norway gender-balancing board quota generate a reduce performance to firms in Norway in post 2004 period. This statement supported by research by (Alm \& Winberg, 2016) that proves woman director has no impact to the firm performance.

H1: Diversity in gender in board of directors has an effect to financial performance of banks in Indonesia.

Nationality of an individual could also affect perspective and value of a person. (Estélyi \& Nisar, 2016) argues board of directors with various nationality increase the operational performance of all FTSE companies in 2001 until 2011 period. Firm decision to hire a foreign board member is a result of firm considerations to what they would bring to firm as a result of hiring them. This argument was supported 
by (Oxelheim \& Rand øy, 2013) and (Triana \& Asri, 2017) that argues foreign directors increase the firms' performance.

Meanwhile (Masulis et al., 2012) argues that foreign board members have a hard time of understanding national policy, accounting and government standard compared to non-foreign board members. This could put them in the hard position and there will be none or a few bad consequences to the firm in the decisions making process. This argument was supported by (Miletkov et al., 2012), although their research focused on one particular factor that encourage firms to consider having a foreign board member.

H2: Diversity in nationality in board of directors has an effect to financial performance of banks in Indonesia.

Experience and educational background are a few of the criteria that firms need in a board member. Member with many experiences will be much more desirable to the firm. Because of that there is a big possibility of older individual to be chosen as board of directors' member. There is also an evident of preference of older age groups to be chosen, but there has been a movement to promote firms to hire a younger person to be one of the members. Firms in Australia that have several younger board members are proven have a better performance (Kang et al., 2007). (Darmadi, 2010) also find that younger board members have a significant effect to the market performance. Younger directors believed to be more energetic, agile and open to innovation. They also have a better understanding to the next generation of customers. Firms with board of directors' members with a wide range of age will have a better understanding with stakeholders with various age groups. It is important to note that although it is better to have a younger member in the board of directors, there should be no dominant age group because it might cause a bias result at the decisions making process between directors.

(Talavera et al., 2018) find different result in their findings. In their research in banks in China, younger members did not bring any increase in bank performance. Because there is a different of generation between younger members with older members, there is limitations of communication between age groups and it would cause an internal conflict between those two groups.

H3: Diversity in age in board of directors has an effect to financial performance of banks in Indonesia.

\section{METHODOLOGY}

\section{DATA AND SAMPLE}

This study uses financial data of banks in Indonesia over the period of 2014-2018, which is observed yearly. The data of board of directors was obtain from each bank annual statement. All dataannual statement and financial ratios-were obtained from Indonesia Stock Exchange (IDX)'s website, banks' official websites, and Thomson Reuters Data Stream. Sample used for this study is conventional banks in Indonesia. Syariah banks is not included as a sample because Syariah banks' data has a different with conventional banks' data and could not be generalized. With five years research period total sample is 180 data observation from 35 banks in Indonesia.

\section{VARIABLE AND MODEL}

The dependent variable used in this study is banks' performance which measured by Tobin's $Q$ (called Q). Q is used as the market-based measurement of banks' performance. Tobin's Q calculated as follows,

$$
\frac{\text { Total Asset }(B V)-\text { Common Equity }(B V)+\text { Common Equity }(M V)}{\text { Total Asset }(B V)}
$$


This proxy is obtained from previous study by (García-meca et al., 2015). Return on Asset (ROA) also used as another measurement to test the robustness of the analysis using $Q$ as the measurement. ROA is used as the accounting-based measurement. As for the independent variables, authors used gender, nationality and age to represent diversity of the board of directors. The operational of the independent variables are as follows,

Table 1. Independent Variables and Operationalization

\begin{tabular}{llc}
\hline \multicolumn{2}{l}{ Independent Variables } & Operationalization \\
\hline \multirow{2}{*}{ Gender } & $\begin{array}{l}\text { Percentage }(\%) \text { of woman board } \\
\text { member }\end{array}$ & $\frac{\text { The number of woman board member }}{\text { The total number of board of directors }}$ \\
Nationality & Percentage (\%) of foreign board member & $\frac{\text { The number of foreign board member }}{\text { Age total number of board directors }}$ \\
& $\begin{array}{l}\text { Coefficient of variation of board } \\
\text { members' age }\end{array}$ & $\frac{\text { The standard deviation of board members'age }}{\text { Average total of board members'age }}$ \\
\hline
\end{tabular}

Table 1 shows the independent variables used for this paper and also the operationalization of the variables. The calculation for independent variable diversity in age was adopted from the previous research by (Talavera et al., 2018). Control variables also obtained to avoid results being bias. These control variables were found has affect related to the board and bank structure (García-meca et al., 2015). The control variables are as follows,

Table 2Control Variables and Definitions

\begin{tabular}{|c|c|c|}
\hline \multicolumn{2}{|c|}{ Control Variables } & Definition \\
\hline & Board size & The total number of the member of board of director \\
\hline Structure & Board independence & Percentage $(\%)$ of independent board member \\
\hline Structure & Board activity & The total number of board of directors meeting in 1 year \\
\hline Bank & Bank Size & Represented by the logarithm of the book value of the total asset \\
\hline Structure & Loans & {$\left[\frac{\text { Total loan }}{\text { Total aset }(B V)}\right]$} \\
\hline
\end{tabular}

Table 2 shows the control variables used in this paper and also the definition of the variables. The model used for this research was adopted from the previous studies by (García-meca et al., 2015) and with additional variable of diversity in age with the calculation adopted from previous study by(Talavera et al., 2018). In previous model, researcher used Duality as one of the control variables. Duality represent the dummy variable of whether or not the chief executive officer (CEO) also served as the boards' chairman. Because in Indonesia, CEO is also served as the boards' chairman, we decided to not use Duality as one of the control variables.

$$
\begin{gathered}
Q=B_{0}+b_{1} \% \text { WOMEN }_{i t}+b_{2} \% \text { FOREIGNERS }_{i t}+b_{3} \% \text { AGE }_{i t}+b_{4} \text { BoardSize }_{i t}+b_{5} \% \text { Indep }_{i t}+b_{6} \text { Activity }_{i t}+b_{7} \\
\text { BankSize }_{i t}+b_{8} \text { Loans }_{i t}+\Sigma b_{j} \text { Country }_{i}+\Sigma b_{k} \text { Year }_{t}+\eta_{i}+\eta_{i t}
\end{gathered}
$$

(Model 1)

This study also using panel data with the purpose of calculating bank performance in a several year period. GMM estimator method was used in this research as previously suggested by Arellano \& Bond (1991). The endogeneity problem that might occur could be avoided by using GMM estimator method.

Table 3. Descriptive Statistic

\begin{tabular}{llllll}
\hline & Mean & Median & Maximum & Minimum & Std Deviation \\
ROA & 1.07 & 1.02 & 1.60 & 0.86 & 0.14 \\
\%Gender & 0.01 & 0.01 & 0.03 & -0.06 & 0.01 \\
\%Foreigner & 21 & 20 & 75 & 0 & 0.19 \\
Age & 8 & 0 & 50 & 0 & 0.13 \\
\hline
\end{tabular}




\begin{tabular}{llllll} 
Board Activity & 29.21 & 25 & 188 & 2 & 21.34 \\
\%Board Independency & 4.15 & 0 & 40 & 0 & 0.08 \\
Board Size & 6.66 & 6 & 12 & 3 & 2.66 \\
Loan & 0.16 & 0.07 & 4.67 & 0 & 0.48 \\
Bank Size & 10.21 & 10.39 & 14.68 & 4.48 & 2.39 \\
\hline
\end{tabular}

Table 3 show the mean, median, maximum, minimum and standard deviation of the variables in our final sample for this research. On average the number of members of the board of directors in the sample is 12 , with a low percentage of woman member and also foreigner which are $21 \%$ and $8 \%$ respectively. it is important to note that not all sample has woman nor foreigner in their board of directors' members. The average variable AGE is 0.10 with the maximum number of 0.31 , the bigger the number it means the range number of board of directors ages are more varies.

\section{RESULTS AND FINDINGS}

Table 4 show the correlation between dependent variables, independent variables and control variables. In the table shows that independent variable with the highest correlation with $Q$ is \%FOREIGNER and control variable with the highest correlation with $Q$ is Bank Size. Meanwhile independent variable with the highest correlation with ROA is \%GENDER and control variable with the highest correlation is also Bank Size.

Table 5 show the result for the proposed model that show the effect of diversity in gender, nationality and age in the board of directors. With the measurement using Tobin's $Q$, the result shows that variable AGE (Prob. 0.0474) has an effect to the banks' performance in Indonesia. Q used as the accounting measurement of performance. The result of effect of diversity in age is statistically significant at the level of $95 \%$. It means that banks that have board members with wide age group has a better financial performance compared to banks that only has one group of board of directors' members. This result supported the evidence of (Darmadi, 2010; Kang et al., 2007) that there is a significant effect to the performance of the firm when firm hire a younger board member.

Table 4. Correlation between variables

\begin{tabular}{|c|c|c|c|c|c|}
\hline Correlation & $\mathbf{Q}$ & ROA & \%Gender & \%Foreigner & Age \\
\hline Q & 1.0000 & & & & \\
\hline ROA & 0.5006 & 1.0000 & & & \\
\hline$\%$ GENDER & -0.0423 & -0.1554 & 1.0000 & & \\
\hline \%FOREIGNER & -0.0587 & -0.0076 & 0.1628 & 1.0000 & \\
\hline AGE & 0.0087 & -0.0703 & 0.2440 & 0.0705 & 1.0000 \\
\hline Board Activity & -0.0042 & 0.1959 & -0.0896 & -0.0102 & -0.0364 \\
\hline Board Independency & 0.0543 & 0.0059 & 0.2238 & -0.0517 & 0.0423 \\
\hline Board Size & 0.1397 & 0.4881 & 0.0207 & 0.2597 & 0.1004 \\
\hline Loans & -0.1138 & -0.0836 & 0.0796 & -0.0610 & 0.1394 \\
\hline \multirow[t]{2}{*}{ Bank Size } & 0.2282 & 0.7590 & -0.0308 & 0.1778 & -0.0470 \\
\hline & $\begin{array}{l}\text { Board } \\
\text { Activity }\end{array}$ & $\begin{array}{l}\text { \%Board } \\
\text { Independency }\end{array}$ & Board Size & Loans & Bank Size \\
\hline Board Activity & 1.0000 & & & & \\
\hline Board Independency & 0.0242 & 1.0000 & & & \\
\hline Board Size & 0.3862 & 0.0279 & 1.0000 & & \\
\hline Loans & -0.0214 & -0.1430 & -0.1388 & 1.0000 & \\
\hline Bank Size & 0.4603 & -0.0215 & 0.8476 & -0.1654 & 1.0000 \\
\hline
\end{tabular}

It also proves the theory that younger members could bring increase of performance from the creativity and innovation they could provide. Meanwhile in these results also shows that other 
independent variables such as gender diversity (\%GENDER) and nationality diversity (\%FOREIGNER) has no effect to the bank performance. It is important to mention that several banks that was used as sample have no woman member or foreign member in the board of directors.

Table 5. Result of the GMM estimator model

\begin{tabular}{llcc}
\hline \multirow{2}{*}{ Independent Variables } & \multicolumn{3}{c}{ Dependent Variable (Tobin's Q) } \\
\cline { 2 - 4 } & Coef. & t-Stat & Prob. \\
\hline \%GENDER & 0.0489 & 0.5665 & 0.5722 \\
\%FOREIGNER & 0.0353 & 0.4147 & 0.6791 \\
AGE & 0.2999 & -2.0040 & 0.0474 \\
Board Activity & -0.0002 & -0.3370 & 0.7367 \\
\%Board Independency & 0.0542 & 0.2576 & 0.7972 \\
Board Size & 0.0080 & 0.7918 & 0.4301 \\
Bank Size & 0.0166 & 1.8125 & 0.0725 \\
Loan & -0.1419 & -1.2285 & 0.2217 \\
\hline
\end{tabular}

Regarding the control variables, the result shows that variable bank size (Prob. 0.0725) has an effect to the bank performance. This result means that the size of the bank also affects the performance of the banks in Indonesia. Bigger bank usually managed better that would result to a better performance.

\section{Robust ANALYSIS}

Table 6 shows the result of the robust analysis. In this analysis ROA is uses as the measurement of the performance of the bank. Return on Asset represent the market measurement of the firm. The result shows that the percentage of foreigner as board of directors' member has an effect to the performance of the bank with Prob. $\mathbf{0 . 0 0 0 6 2}$. The result of effect of diversity in nationality is statistically significant at the level of $99 \%$. It means banks that have at least one foreign board member, have a possibility of a better performance compared to other banks that do not have any foreigners as a board member.

Table 6. Result of Robust Analysis

\begin{tabular}{lccc}
\hline \multirow{2}{*}{ Independent Variables } & \multicolumn{3}{c}{ Dependent Variable (ROA) } \\
\cline { 2 - 4 } & Coef. & t-Stat & Prob. \\
\hline \%GENDER & -0.00324 & -1.26655 & 0.20777 \\
\%FOREIGNER & 0.00899 & -3.51493 & 0.00062 \\
AGE & 0.00027 & 0.07910 & 0.93708 \\
Board Activity & -0.00001 & -0.57907 & 0.56363 \\
Board Independency & 0.00827 & 1.51974 & 0.13121 \\
Board Size & 0.00023 & 0.85743 & 0.39292 \\
Bank Size & 0.00502 & 21.93910 & 0.00000 \\
Loan & -0.00001 & -0.02188 & 0.98258 \\
\hline
\end{tabular}

This result is supported by previous research by (Estélyi \& Nisar, 2016) and also previous research by (Oxelheim \& Randøy, 2013). They stated that firms with various nationality in the board of directors has an increase in their performance.

\section{CONCLUSION}

In summary, this research studies the effect of diversity in the board of directors to the banks' financial performance. We used panel data set from banks in Indonesia with an exception of Syariah banks with research period between 2014 to 2018. Using both accounting measurement with Tobin's Q and also market measurement with ROA, the result as follows. Based on the result, shows diversity in gender or woman board member that was calculated by the percentage of the number of women as one 
of the members of the board of directors does not have an effect to the financial performance of banks in Indonesia. This result could be driven by the low number of women as one of the board members in the sample. Although the maximum percentage of woman in the sample is 75 percent, the average number of women in the board of directors (21\%) shows that many banks in Indonesia still do not have any woman in the board of directors.

Meanwhile, based on the result proves that diversity in age and nationality have an effect to the bank performance in Indonesia. Age diversity was calculated by the calculation that was adopted from the previous research by (Talavera et al., 2018). Firms that hire younger individual as the member of the board of directors proves to have an effect to the firms. This result is supported by (Kang et al., 2007) that proves that younger members bring an increase to the performance of the firm. This could be the result of younger members are more likely to bring creativity and better understanding to customers from different age groups. Younger members are also more open to innovation compared to members from older generations. Diversity in nationality also proven has an effect to the performance of the bank. This finding is supported by previous research of (Estélyi \& Nisar, 2016) that prove that various ethnic nationality could bring an increase of performance.

Regarding control variable, variable bank size shows a significant effect to the bank performance. This result means that bigger bank usually tends to have a better monitoring and management as a result bigger banks tends to have better performance compared to smaller banks.

\section{Reference:}

Adams, R. B., \& Ferreira, D. (2009). Women in the boardroom and their impact on governance and performance. 94, 291-309. https://doi.org/10.1016/j.jfineco.2008.10.007

Alm, M., \& Winberg, J. (2016). How Does Gender Diversity on Corporate Boards Affect the Firm Financial Performance? An Empirical Investigation of Swedish OMXlisted Firms. https://gupea.ub.gu.se/handle/2077/41620

Berger, A. N., Kick, T., \& Schaeck, K. (2014). Executive board composition and bank risk taking. Journal of Corporate Finance, 28, 48-65. https://doi.org/10.1016/j.jcorpfin.2013.11.006

Block, D., Gerstner, A., Block, D., \& Gerstner, A. (2016). Penn Law : Legal Scholarship Repository OneTier vs. Two-Tier Board Structure : A Comparison Between the United States and Germany Class of 2016 One-Tier vs. Two-Tier Board Structure : A Comparison Between the United States and Germany Financial Regulat.

Boglárka, S. (2012). One and two-tier corporate governance systems. International Law Office. https://www.internationallawoffice.com/Newsletters/Corporate-Commercial/Hungary/Nagys-Trcsnyi/One-and-two-tier-corporate-governance-systems

Carpenter, M. A., Sanders, W. G., \& Gregersen, H. B. (2001). Bundling Human Capital with Organizational Context: The Impact of International Assignment Experience on Multinational Firm Performance and CEO Pay. Academy of Management Journal, 44, 493-511. https://doi.org/10.2307/3069366

Catalyst. (2018). Why Diversity and Inclusion Matter: Quick Take / Catalyst. https://www.catalyst.org/research/why-diversity-and-inclusion-matter/

Darmadi, S. (2010). Board Diversity and Firm Performance: The Indonesian Evidence. Corporate Ownership and Control, 9. https://doi.org/10.22495/cocv8i2c4p4

Dieleman, M. (2012). Female Footprints in IDX-listed Companies.

Estélyi, K. S., \& Nisar, T. M. (2016). Diverse boards : Why do fi rms get foreign nationals on their boards ? Journal of Corporate Finance, 1-19. https://doi.org/10.1016/j.jcorpfin.2016.02.006

Fama, E. F., Jensen, M. C., Law, J., \& Conference, P. P. A. (2007). Separation of Ownership and Control SEPARATION OF OWNERSHIP A N D CONTROL *. 26(2), 301-325.

Fogel, K., Lee, K., Lee, W., \& Palmberg, J. (2013). Foreign Direct Investors as Change Agents: The Swedish Firm Experience. Corporate Governance: An International Review, 21. https://doi.org/10.1111/corg.12035 
García-meca, E., García-sánchez, I., \& Martínez-ferrero, J. (2015). Board diversity and its effects on bank performance : An international analysis. 53, 202-214.

https://doi.org/10.1016/j.jbankfin.2014.12.002

Ghosh, S. (2016). Why is it a m an's world, after all ? Women on bank boards in India. Economic Systems. https://doi.org/10.1016/j.ecosys.2016.05.007

Jawapos. (2017). Kesetaraan Gender di Dunia Industri, Jumlah Pekerja Perempuan Naik.

https://www.jawapos.com/ekonomi/30/11/2017/kesetaraan-gender-di-dunia-industri-jumlahpekerja-perempuan-naik/

Jensen, C., \& Meckling, H. (1976). THEORY OF THE FIRM : MANAGERIAL BEHAVIOR, AGENCY COSTS AND OWNERSHIP STRUCTURE I . Introduction and summary In this paper WC draw on recent progress in the theory of (1) property rights, firm. In addition to tying together elements of the theory of e. 3, 305-360.

Kang, H., Cheng, M., \& Gray, S. J. (2007). Corporate Governance and Board Composition : diversity and independence of Australian boards. 15(2), 194-207.

Manning, J. (2019). Achieving Diversity and Inclusion in the Banking Sector: a Work in Progress. International Banker. https://internationalbanker.com/banking/achieving-diversity-andinclusion-in-the-banking-sector-a-work-in-progress/

Masulis, R. W., Wang, C., \& Xie, F. (2012). Globalizing the boardroom - The effects of foreign directors on corporate governance and firm performance \$. Journal of Accounting and Economics, 53(3), 527-554. https://doi.org/10.1016/j.jacceco.2011.12.003

McColgan, P. (2001). Agency theory and corporate governance: a review of the literature from a UK perspective. Department of Accounting and Finance University of Strathclyde, May, 0-44.

Miletkov, M., Poulsen, A., \& Wintoki, M. (2012). A Multinational Study of Foreign Directors on Non-U.S. Corporate Boards.

Myatt, M. (2013). Top 10 Reasons Diversity Is Good For The Boardroom. Forbes. https://www.forbes.com/sites/mikemyatt/2013/11/18/top-10-reasons-diversity-is-good-forthe-boardroom/\#72260c5c1b90

Owen, A. L., \& Temesvary, J. (2018). The performance effects of gender diversity on bank boards R. Journal of Banking and Finance, 90, 50-63. https://doi.org/10.1016/j.jbankfin.2018.02.015

Oxelheim, L., \& Rand $\varnothing y$, T. (2013). Globalization of Monitoring Practices: The Case of American Influences on the Dismissal Risk of European CEOs. Journal of Economics and Business, 70. https://doi.org/10.2139/ssrn.2228849

Pathan, S., \& Faff, R. (2013). Does board structure in banks really affect their performance ? Journal of Banking and Finance, 37(5), 1573-1589. https://doi.org/10.1016/j.jbankfin.2012.12.016

Talavera, O., Yin, S., \& Zhang, M. (2018). International Review of Financial Analysis Age diversity, directors ' personal values, and bank performance. International Review of Financial Analysis, 55(October 2017), 60-79. https://doi.org/10.1016/j.irfa.2017.10.007

Triana, \& Asri, M. (2017). THE IMPACT OF FEMALE DIRECTORS ON FIRM PERFORMANCE : 32(1), $19-32$.

Yang, P., Riepe, J., Moser, K., Pull, K., \& Terjesen, S. (2019). Women directors, firm performance, and firm risk : A causal perspective. The Leadership Quarterly, May 2018, 101297. https://doi.org/10.1016/j.leaqua.2019.05.004 